\title{
Characteristics of the Western European ecological group barley varieties in the North- Western region of the Russian Federation
}

\author{
Olga Kovaleva and Kseniia Lukina* \\ Federal Research Center N. I. Vavilov All-Russian Institute of Plant Genetic Resources (VIR), \\ 191031 Bolshaya Morskaya st., 42-44, St. Petersburg, Russia
}

\begin{abstract}
In the North-West region, spring barley is the main grain fodder crop. The variety is an effective and most affordable means of increasing the harvest and quality of the grain. The studying selection material for breeding ensures success in the creation of new varieties. European varieties are characterized by resistance to powdery mildew, which is a limiting factor of breeding in the North-West region. This work aimed to find new sources of agrobiological valuable traits. In 2016-2018, which differed in weather conditions, 32 varieties of spring barley were studied on the field of the Pushkin Laboratory of VIR. As a result of studying a set of samples of the Western European ecological group, according to the main agrobiological valuable traits sources for breeding in the North-West region were identified: early maturing, semi-dwarf, large-grain variety "Brucefield" (к-31555, parallelum, Germany); semi-dwarf, large-grain variety - "Brennus" (к-31331, nutans, France); middle-maturity, highyielding, large-grain, semi-dwarf, resistant to lodging, with an adaptation coefficient more than 1 - "Niagara" (к-31334, nutans, France), "Tocada" (к-31341, deficiens, Germany), "Juhata" (к-31346, nutans, Germany), "KWS Alciana" (к-31348, nutans, Germany).
\end{abstract}

\section{Introduction}

Barley is the main grain-fodder crop of the North-West region. In the Leningrad region, barley occupies $63 \%$ of the grain wedge [1]. The creation of new varieties is the most important resource for the development of agriculture. Increasing the quantity and quality of the yield depends on the properties of the variety.

Correctly select material for breeding ensures success in the creation of new varieties. The world collection of VIR includes more than 18 thousand barley samples. It is the main source of initial material for breeding. Recently, varieties of foreign selection occupy $40 \%$ of the economic varieties in Russia [2]. These varieties belong to the Western European agroecological group and are mainly represented by varieties from Germany and France. Varieties of European selection are characterized by resistance to powdery mildew,

\footnotetext{
* Corresponding author: k.lukina@vir.nw.ru
} 
provided by the presence of the mloll gene, which is one of the main factors of the advantage of these varieties over varieties of Russian selection [3].

At present, the gene pool of the VIR collection has been replenished with a large number of new Western European varieties. The cultivars are obtained from the European Union breeding firms. In order to identify sources and donors of valuable traits to the main breeding directions, it is necessary to study this material extensively for certain soil and climatic conditions. In this regard, the study of the West European ecological group materials in the conditions of the North-Western Russia region is actually. This work aims to study new barley varieties from the West European ecological group of the world VIR collection in the conditions of the North-West region and identify the sources for breeding.

\section{Materials and methods}

32 varieties of spring barley obtained from European breeding institutions were studied at Pushkin (Pushkin and Pavlovsk laboratories of VIR) for three years (2016-2018). All varieties are two-rowed and are represented by varieties of nutans and deficiens, and only one six-row variety - "Brucefield" (parallelum).

According with the Guidelines for the study of the world collection of barley and oats [4] the study was carried out. The zoned, mid-ripening and widely cultivated variety "Suzdalets" (к-30314, nutans, Moscow district), the previously zoned, mid-ripening and adaptive cultivar "Krinichniy" (к-27605, nutans, Belarus) and the six-row zoned and midearly cultivar "Belogorskiy" (к-22089, pallidum, rikotense, Leningrad district) and early maturity cultivar "Potra" (к-26209, parallelum, Finland) were used as standards. The weather conditions during the growing season varied significantly (Table 1).

Table 1. Meteorological conditions Pushkin 2016-2018.

\begin{tabular}{|c|c|c|c|c|}
\hline \multicolumn{5}{|c|}{ Amount of precipitation, mm } \\
\hline Month & $\mathbf{2 0 1 6}$ & $\mathbf{2 0 1 7}$ & $\mathbf{2 0 1 8}$ & Average long-term values \\
\hline May & 17,8 & 13,4 & 13,7 & 44,1 \\
\hline June & 63,8 & 68,5 & 23,1 & 65,2 \\
\hline July & 174,2 & 122,5 & 95,2 & 75,6 \\
\hline August & 174,3 & 147,6 & 61,6 & 80,3 \\
\hline \multicolumn{5}{|c|}{ Average daily air temperature, ${ }^{\circ} \mathbf{C}$} \\
\hline Month & $\mathbf{2 0 1 6}$ & $\mathbf{2 0 1 7}$ & $\mathbf{2 0 1 8}$ & Average long-term values \\
\hline May & 17,5 & 9,4 & 15,1 & 10,85 \\
\hline June & 18 & 13,6 & 16,2 & 15,55 \\
\hline July & 19,6 & 16,5 & 20,1 & 18,3 \\
\hline August & 18,2 & 17,4 & 19,2 & 16,45 \\
\hline
\end{tabular}

In 2016 , in May, the average temperature was $17.5^{\circ} \mathrm{C}$, it was $7^{\circ} \mathrm{C}$ higher than usual, precipitation was less than normal. In June, the weather conditions did not differ significantly from the average for summer indicators, it was warm and there was enough rainfall for good plant development. July and August were characterized by an excess of rainfall, it was led to the formation of additional tillerings. Weather conditions were favorable for the high yield due to productive tillerings.

During the growing season of 2017, weather conditions significantly differed from the average long-term indicators. Average temperatures in May, June and July were below normal. In May, the precipitation was insufficient in 3 times lower than the norm, in June the monthly norm of precipitation fell, July and August were characterized by excessive amounts of precipitation. Lack of heat at the beginning and in the middle of the growing 
season promoted later heading; the growing season was on average 10 days longer. In general, the weather conditions were quite favorable for the growth and development of barley plants, which led to a high yield.

In 2018 the weather conditions were significantly different from the long-term average. Average temperatures were higher than the average multiyear norm. In May and June, precipitation fell 3 times less than the norm. At the beginning of July, the monthly norm of precipitation fell, and later, until the end of the growing season, a drought was observed. The lack of moisture in the soil during the seedling-heading period led to a reduced tillering of barley plants, an increased temperature contributed to the formation of sterility of pollen grains, which led to overgrowth. The lack of rain during the ripening period led to the puffiness of the grain and was reflected in the yield and weight of 1000 grains.

The results were carried out by methods of variance, correlation analyzes according to B.A. Dospekhov and using Microsoft Excel [5]. The coefficient of adaptability was calculated by the method of Zhivodkov L. A. [6].

\section{Results and Discussions}

The creation of early ripening varieties of barley is the most important task for regions of Russia with a short growing season. The introduction of such varieties in the North and North-West regions will ensure the harvesting of barley in the optimal agrotechnical terms. The use of early maturity varieties of barley will allow to store up grain silage and crimped grain in favorable conditions. It will lead to guaranteed obtaining seeds with high sowing qualities. In areas with high temperatures and drought, the use of early maturity varieties with active growth in the first phases of the growing season (seedling-tillering) allows to escaping from summer droughts. Such varieties form a root system quickly, use the reserves of spring moisture and suffer the arid conditions better.

The main direction of breeding in the North-West of Russia is early maturity. According to the results samples maturing earlier than the early maturity standard "Potra" (68 days) were not found. Only one accession - "Brucefield" (к-31555, parallelum, Germany) was mature at the level of "Potra". 2 varieties: "Niagara" (к-31334, nutans, France), "Power" (к31353, nutans, Germany) were maturity as the medium early standard "Belogorskiy" (75 days). The rest of the samples were assigned to the mid-maturity group (more than 75 days) (Figure 1).

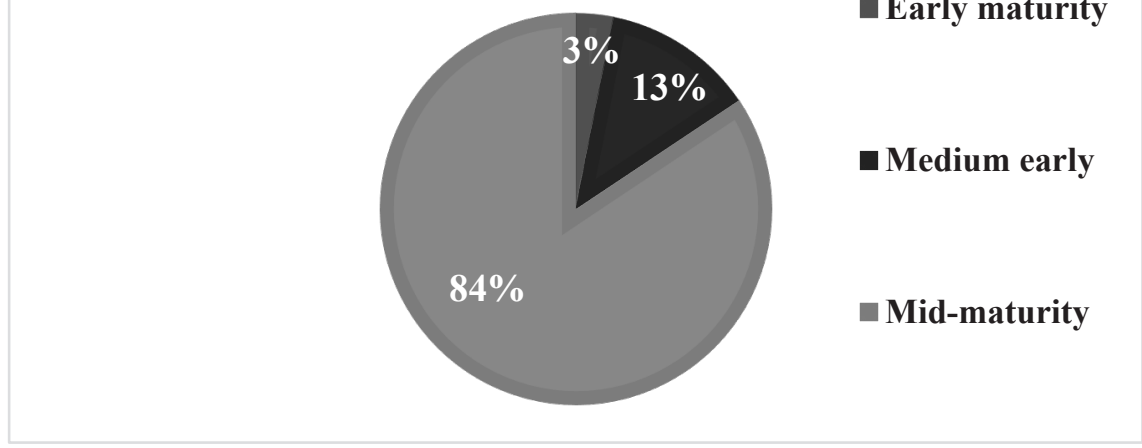

- Early maturity

Fig. 1. Characteristics by the duration of samples vegetative period (Pushkin, 2016-2018).

Barley samples with a short vegetative period and high productivity were identified as sources of early maturity (Table 2). 
Table 2. Early maturity sources (Pushkin, 2016-2018).

\begin{tabular}{|c|c|c|c|c|c|c|c|}
\hline \multirow{2}{*}{$\begin{array}{c}\text { N kat } \\
\text { VIR }\end{array}$} & \multirow{2}{*}{ Origin } & \multirow{2}{*}{ Name } & \multicolumn{3}{|c|}{ Seeding-maturity (days) } & \multirow{2}{*}{$\begin{array}{c}\text { Average } \\
\text { duration of } \\
\text { vegetative period } \\
\text { (days) }\end{array}$} & \multirow{2}{*}{$\begin{array}{l}\text { Yield, } \\
\text { g/m } \mathbf{m}^{2}\end{array}$} \\
\hline & & & 2016 & 2017 & 2018 & & \\
\hline $\begin{array}{c}\text { St } \\
26209\end{array}$ & Finland & Potra & 63 & 75 & 66 & 68 & 332 \\
\hline 31334 & France & Niagara & 66 & 84 & 69 & 73 & 452 \\
\hline 31353 & Germany & Power & 67 & 83 & 74 & 75 & 216 \\
\hline 31555 & Germany & Brucefield & 67 & 76 & 69 & 71 & 344 \\
\hline
\end{tabular}

Lodging is one of the limiting factors in increasing yields in moisture and long daylight hours conditions. Lodging leads to a loss of $10-50 \%$ of the yield, interferes with mechanized harvesting, and disimproves the quality of grain and seeds [7].

Lodging resistance in cereals is closely related to the height and strength of the straw. Short-stemmed plants are generally more resistant to lodging. The varieties of Western European selection have a shortened, dense straw, resistant to lodging. Varieties height of plants over the years of study ranged from 45 to $90 \mathrm{~cm}$. According to the results of a threeyear study, lodging resistant standard variety "Suzdalets" was $80 \mathrm{~cm}$ and variety "Belogorskiy" was $95 \mathrm{~cm}$, although the height changed significantly over the years. Among the studied varieties, sources of lodging resistance with a shortened stem were identified (Table 3).

Table 3. Lodging resistance sources (Pushkin, 2016-2018).

\begin{tabular}{|c|c|c|c|c|c|c|}
\hline \multirow{2}{*}{$\begin{array}{c}\text { N kat } \\
\text { VIR }\end{array}$} & \multirow{2}{*}{ Origin } & \multirow{2}{*}{ Name } & \multicolumn{4}{|c|}{ Plant height, cm } \\
\cline { 4 - 7 } & & & $\mathbf{2 0 1 6}$ & $\mathbf{2 0 1 7}$ & $\mathbf{2 0 1 8}$ & Average \\
\hline $\begin{array}{c}\mathrm{St} \\
22089\end{array}$ & $\begin{array}{c}\text { Leningrad } \\
\text { district }\end{array}$ & Belogorskiy & 103,75 & 107,5 & 75 & 95 \\
\hline $\begin{array}{c}\mathrm{St} \\
27605\end{array}$ & Belarus & Krinichniy & 82,5 & 105 & 75 & 88 \\
\hline $\begin{array}{c}\text { St } \\
30314\end{array}$ & Moscow district & Suzdalets & 80 & 90 & 70 & 80 \\
\hline 31331 & France & Brennus & 55 & 75 & 50 & 60 \\
\hline 31332 & Germany & Solist & 60 & 70 & 50 & 60 \\
\hline 31333 & England & Odyssey & 65 & 70 & 45 & 60 \\
\hline 31343 & Germany & Streit & 70 & 65 & 45 & 60 \\
\hline 31344 & Germany & Steward & 60 & 65 & 50 & 58 \\
\hline 31345 & Germany & Troon & 70 & 65 & 55 & 63 \\
\hline 31346 & Germany & Juhata & 70 & 70 & 55 & 65 \\
\hline 31348 & Germany & KWS Alciana & 75 & 75 & 50 & 67 \\
\hline 31349 & Germany & Lisanne & 65 & 70 & 50 & 62 \\
\hline 31352 & Germany & Publican & 70 & 80 & 60 & 70 \\
\hline 31353 & Germany & Power & 70 & 70 & 55 & 65 \\
\hline 31556 & France & Azalea & 70 & 70 & 45 & 62 \\
\hline
\end{tabular}


Grain productivity is the goal of all agricultural production. It is the important varieties property and is defined as the main factor among the breeding tasks. Grain productivity depends on many traits: productive tillering, grain mass per the main spike, spike length, spikelets number per spike, grains number per spike, weight of 1000 grain. Among the studied varieties, high-yielding samples exceeding the standard by more than $15 \%$ were not found. During 3 years study, productivity varieties at the standards level were identified (Table 4), it should be noted varieties "Niagara" (к-31334, nutans, France), "Tocada" (к31341 , deficiens, Germany), the yield of which exceeds the standards yield by $10 \%$.

The grain size expressed in the weight of 1000 grain is one of the most important yield structure traits. Weather conditions, violation of moisture supply, mineral nutrition of plants during the grain formation and maturity periods are significantly influenced on the grain size.

Table 4. Sources of high yield (Pushkin, 2016-2018).

\begin{tabular}{|c|c|c|c|c|c|c|}
\hline \multirow{2}{*}{$\begin{array}{c}\text { N kat } \\
\text { VIR }\end{array}$} & \multirow{2}{*}{ Origin } & \multirow{2}{*}{ Name } & \multicolumn{4}{|c|}{$\begin{array}{c}\text { Yield, } \\
\mathbf{g} / \mathbf{m}^{\mathbf{2}}\end{array}$} \\
\cline { 4 - 7 } & & & $\mathbf{2 0 1 6}$ & $\mathbf{2 0 1 7}$ & $\mathbf{2 0 1 8}$ & \multirow{2}{*}{ Average } \\
\hline $\begin{array}{c}\text { St } \\
27605\end{array}$ & Belarus & Krinichniy & 325 & 517,5 & 207,5 & 350 \\
\hline $\begin{array}{c}\text { St } \\
30314\end{array}$ & Moscow district & Suzdalets & 190 & 645 & 270 & 368 \\
\hline 31331 & France & Brennus & 260 & 690 & 160 & 370 \\
\hline 31332 & Germany & Solist & 220 & 755 & 155 & 377 \\
\hline 31333 & England & Odyssey & 240 & 735 & 100 & 358 \\
\hline 31334 & France & Niagara & 300 & 870 & 185 & 452 \\
\hline 31339 & Germany & Ursa & 260 & 710 & 218 & 396 \\
\hline 31341 & Germany & Tocada & 250 & 815 & 290 & 452 \\
\hline 31345 & Germany & Troon & 200 & 565 & 274 & 346 \\
\hline 31346 & Germany & Juhata & 240 & 675 & 250 & 388 \\
\hline 31347 & Germany & KWS & 220 & 685 & 257 & 387 \\
\hline 31348 & Germany & $\begin{array}{c}\text { KWS } \\
\text { Alciana }\end{array}$ & 220 & 705 & 252 & 392 \\
\hline
\end{tabular}

Varieties "Brennus" (к-31331, nutans, France), "Niagara" (к-31334, nutans, France), "Juhata" (к-31346, nutans, Germany) were identified as coarse grain sources for the NorthWest region with weight of 1000 grain more than $45.0 \mathrm{~g}$ in dry years. Sources of coarse grain corresponding to the standards are shown in Table 5. We found that the Western European barley varieties yield depends on the weight of 1000 grain $(r=0.8 \pm 0.03)$. Other characteristics that determine the yield no correlation was found.

Table 5. High weight of 1000 grain sources (Pushkin, 2016-2018).

\begin{tabular}{|c|c|c|c|c|c|c|}
\hline \multirow{2}{*}{$\begin{array}{c}\text { N kat } \\
\text { VIR }\end{array}$} & \multirow{2}{*}{ Origin } & \multirow{2}{*}{ Name } & \multicolumn{4}{|c|}{ Weight of 1000 grain, g } \\
\cline { 4 - 7 } & & & $\mathbf{2 0 1 6}$ & $\mathbf{2 0 1 7}$ & $\mathbf{2 0 1 8}$ & Average \\
\hline $\begin{array}{c}\text { St } \\
27605\end{array}$ & Belarus & Krinichniy & 40,53 & 49,86 & 42,02 & 44,137 \\
\hline $\begin{array}{c}\text { St } \\
26209\end{array}$ & Finland & Potra & 44,72 & 51,26 & 44,04 & 46,673 \\
\hline St & Moscow district & Suzdalets & 33,02 & 54,28 & 41,72 & 43,007 \\
\hline
\end{tabular}




\begin{tabular}{|c|c|c|c|c|c|c|}
\hline 30314 & & & & & & \\
\hline 31331 & France & Brennus & 35,82 & 59,1 & 41,32 & 45,413 \\
\hline 31334 & France & Niagara & 40,52 & 56,46 & 44,74 & 47,24 \\
\hline 31340 & Germany & Westminster & 34,72 & 53,92 & 41,64 & 43,427 \\
\hline 31341 & Germany & Tocada & 40,56 & 45,44 & 45,8 & 43,933 \\
\hline 31346 & Germany & Juhata & 38,84 & 55,34 & 47,74 & 47,307 \\
\hline 31348 & Germany & KWS Alciana & 32,8 & 54,94 & 46,76 & 44,833 \\
\hline 31555 & Germany & Brucefield & 38,76 & 52,26 & 43,5 & 44,84 \\
\hline
\end{tabular}

15 varieties had got an adaptation coefficient more than 1. Varieties "Niagara" (к-31334, France), "Tocada" (к-31341, Germany), "Juhata" (к-31346, Germany) have been identified with the highest adaptation coefficients.

\section{Conclusions}

As a result of studying a set of the Western European samples sources for breeding in the North-West region were identified. Cultivars "Brucefield" (к-31555, parallelum, Germany) early maturing, medium-height, large-grain, "Brennus" (к-31331, France) semi-dwarf, large-grain mid-season variety, "Niagara" (к-31334, nutans, France), "Tocada" (к-31341), "Juhata" (к-31346), "KWS Alciana" (к-31348) from Germany high-yielding, large-grain, semi-dwarf, high resistance to lodging and an adaptation coefficient more 1 can be used in the breeding process in the North-West region of the Russian Federation.

\section{Acknowledgements}

This publication was prepared within the framework of VIR's state budget project No. 0662-2019-0006.

\section{Conflicts of Interest}

Declare conflicts of interest or state "The authors declare no conflict of interest."

\section{References}

1. T. Danilova, S. Sinitsyn, Prospects for the development of grain production in the Northwest Federal District of the Russian Federation in Proceedinds of the International Congress of Agriculture "Prospects for the development of agroindustrial complex of Russia in the conditions of membership in the WTO", St. Petersburg: ZAO "Expoforum", 155-156 (2013) [in Russian]

2. State Register for Selection Achievements Admitted for Usage (National List), "Plant varieties", 1, 719 (Moscow: FGBNU Rosinformagrotekh, 2021) [in Russian]

3. A. Dreiseitl, Plant Breeding 136 (3), 351-356 (2017) DOI:10.1111/pbr.12471

4. I. Loskutov, O. Kovaleva, E. Blinova, Methodical instruction for the study and conservation of the world collection of barley and oats, 63 (St. Petersburg: VIR, 2012) [in Russian]

5. B. Dospekhov, Methodology of field trial (Moscow: Agropromizdat, 1985) [in Russian]

6. L. Zhivotkov, Z. Morozova, L. Sekatueva, Plant Breeding and Seed Production, 2, 3-6 (1994) [in Russian] 
7. V. Kovalev, K. Kosareva, Zhurnal Sel'skokhozyaistvennaya biologiya, 1, 72-81 (1990) [in Russian] 